\title{
An earlier origin for the Acheulian
}

\author{
Christopher J. Lepre ${ }^{1,2}$, Hélène Roche ${ }^{3}$, Dennis V. Kent ${ }^{1,2}$, Sonia Harmand ${ }^{3}$, Rhonda L. Quinn ${ }^{2,4}$, Jean-Philippe Brugal ${ }^{5}$, \\ Pierre-Jean Texier ${ }^{6}$, Arnaud Lenoble ${ }^{6}$ \& Craig S. Feibel ${ }^{2}$
}

The Acheulian is one of the first defined prehistoric technocomplexes and is characterized by shaped bifacial stone tools ${ }^{1-3}$. It probably originated in Africa, spreading to Europe and Asia perhaps as early as $\sim 1$ million years $(\mathrm{Myr})$ ago $^{4-6}$. The origin of the Acheulian is thought to have closely coincided with major changes in human brain evolution, allowing for further technological developments ${ }^{7,8}$. Nonetheless, the emergence of the Acheulian remains unclear because well-dated sites older than 1.4 Myr ago are scarce. Here we report on the lithic assemblage and geological context for the Kokiselei 4 archaeological site from the Nachukui formation (West Turkana, Kenya) that bears characteristic early Acheulian tools and pushes the first appearance datum for this stone-age technology back to $1.76 \mathrm{Myr}$ ago. Moreover, co-occurrence of Oldowan and Acheulian artefacts at the Kokiselei site complex indicates that the two technologies are not mutually exclusive time-successive components of an evolving cultural lineage, and suggests that the Acheulian was either imported from another location yet to be identified or originated from Oldowan hominins at this vicinity. In either case, the Acheulian did not accompany the first human dispersal from Africa ${ }^{9,10}$ despite being available at the time. This may indicate that multiple groups of hominins distinguished by separate stone-tool-making behaviours and dispersal strategies coexisted in Africa at $1.76 \mathrm{Myr}$ ago.

Sediments of the Nachukui formation exposed along the northwest shoreline of modern Lake Turkana in Kenya ${ }^{11}$ (Fig. 1 and Supplementary Fig. 1) preserve several rich archaeological site complexes, among which is Kokiselei. Thus far, this complex is defined by ten sites, eight of which are found within a discrete 5-m interval of the middle part of the nearly 170-m-thick Kaitio member. Six of those sites have been tested or largely excavated but many other potential sites have been pinpointed. Most of these Kokiselei sites contain typical core/flake Oldowan assemblages ${ }^{12}$. Kokiselei 4 (KS4), however, holds an exceptional lithic assemblage that confirms the co-occurrence of the Oldowan and Acheulian at this site complex, indicating that the behavioural repertoire of early hominins in the area incorporated both technologies.

The KS4 assemblage (Supplementary Fig. 2) is characterized by the presence of pick-like tools with a trihedral or quadrangular section, unifacially or bifacially shaped crude hand-axes, and a few cores and flakes, all derived from the same mudstone bed. A single subsurface, in situ origin for KS4 is ensured by excavations at the main test trench that recovered several spectacular sets of refitted lithic artefacts (Supplementary Fig. 3). To the exception of a few cores made on basalt, the rest of the assemblage has been knapped from large cobbles or tabular clasts of locally available aphiric phonolite ${ }^{13}$. No vertebrate remains have been found within the test trenches, but the mudstone bed has yielded numerous non-human vertebrate fossils. The most frequent taxon is the large-sized hippopotamus Hippopotamus gorgops (adult and juvenile), but suids (Kolpochoerus, Metridiochoerus, Notochoerus?), rhinoceros (Ceratotherium sp.), equids (Equus and Hipparion) and a few carnivores (Panthera, Hyaenidae aff. Crocuta) are also present. Some isolated teeth and post-cranial elements represent bovids, and it is possible to identify Bovini (aff. Syncerus), Reduncini (Kobus sp.) and medium-sized Tragelaphini and Alcelaphini.

Broadly speaking, the Acheulian tools of KS4 come from a 15-20-mthick interbedded series of gravels, sands and mudstones colloquially
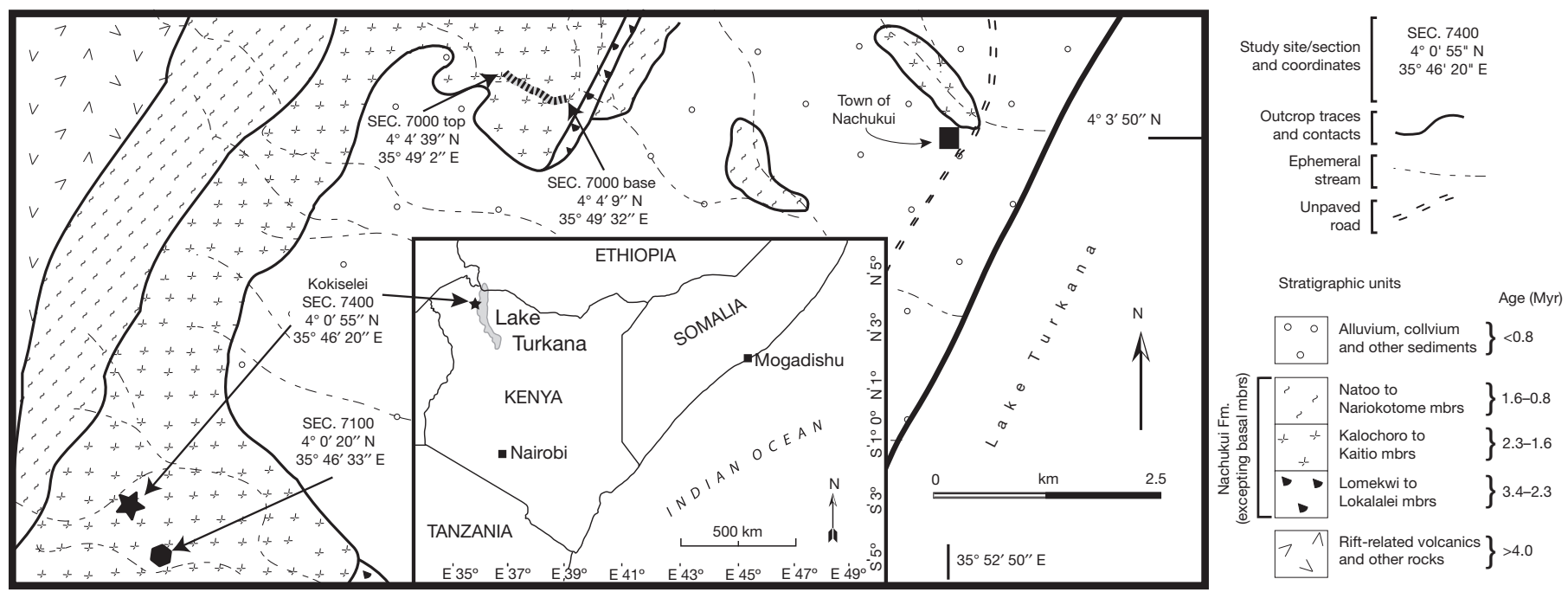

Figure $1 \mid$ Geological $^{11}$ and location map. Note the latitude and longitude coordinates provided for each place of investigation. Section 7000 (SEC. 7000) was surveyed $\sim 200 \mathrm{~m}$ along the ephemeral stream; hence the indications of the base and top are given. The other two-SEC. 7100 and SEC. 7400 (the latter of which is where the Acheulian site KS4 was excavated)-derive from sheer outcrops, and the coordinates for only the top of the sections are given. 
referred to as the bird cliff beach complex (BCBC). Outcrops of the $\mathrm{BCBC}$ are part of a nearly continuous band of sediments belonging to the Kalochoro and Kaitio members that extends for over $7 \mathrm{~km}$ from northeast to southwest along the modern northwest shoreline of Lake Turkana, Kenya (Fig. 1). These members of the Nachukui formation record a transition from predominantly fluvial to lacustrine sedimentation in the Pleistocene Turkana basin during which the rest of East Africa is thought to have undergone ecosystem turnover in response to global climate forcing ${ }^{14}$. A first indication of lacustrine deposits occurs $\sim 35 \mathrm{~m}$ above the base of the Kalochoro member, marked by the appearance of silty/clayey, often thinly bedded and finely laminated, ostracod-rich lacustrine mudstones, which coarsen upwardly into poorly sorted massive mudstones (Supplementary Figs 8-11). Thin lenticular units of gravel and sand become apparent near the top of the Kalochoro member, which heralds the appearance of the $\mathrm{BCBC}$ in the Kaitio member. Lithological units of the BCBC form metre-thick, coarsening-upward cycles of claystone, siltstone and sand and/or gravel. At KS4, the coarsest layers of the BCBC consist of gravelly sands that preserve abundant rhizoconcretions at their tops (Supplementary Figs 10 and 11). Claystones of the cycles contain thin lenses of mollusc shells and are dissected by slickensided fractures that define wedge-shaped aggregates of palaeosols. These claystones, as well as the siltstone, can be very poorly sorted in places and include volcanic granules/pebbles. Such lithostratigraphic and sedimentary patterns suggest a dynamic environment along a palaeo-lakeshore.

In the Kokiselei region the erosive base of the $\mathrm{BCBC}$ occurs varyingly at $1-15 \mathrm{~m}$ above the Kaitio member's lowermost stratigraphic level, which is the KBS tuff ${ }^{11}$ dated by ${ }^{40} \mathrm{Ar} /{ }^{39} \mathrm{Ar}$ to $1.869 \pm 0.021 \mathrm{Myr}^{\mathrm{ago}}{ }^{15}$. The KBS tuff lies $78 \mathrm{~m}$ above the Kalochoro tuff, dated by ${ }^{40} \mathrm{Ar} /{ }^{39} \mathrm{Ar}$ to $2.331 \pm 0.015 \mathrm{Myr} \mathrm{ago}^{16}$, which defines the base of the Kalochoro member ${ }^{11}$. No direct numerical age constraints have been determined for the $\mathrm{BCBC}$; however, regional geological mapping and tephrostratigraphic studies indicate that it is $\sim 150 \mathrm{~m}$ below the base of the Lower Koobi Fora tuff ${ }^{11}$ dated by ${ }^{40} \mathrm{Ar} /{ }^{39} \mathrm{Ar}$ to $1.476 \pm 0.013 \mathrm{Myr}$ ago ${ }^{15}$. Linear extrapolation from the Kalochoro and KBS tuffs and linear interpolation from the KBS and Lower Koobi Fora tuffs broadly constrain the KS4 Acheulian assemblage to between 1.72 and $1.81 \mathrm{Myr}$ ago. Other dated tuffaceous beds between the KBS and Lower Koobi Fora tuffs in the Turkana basin that would further refine stratigraphic position have not been found in the Kokiselei region. To place the KS4 artefacts within a more constrained age context, we collected 148 orientated samples for palaeomagnetic analysis (see Supplementary Methods and Supplementary Figs 4-7) from sections of outcrop exposed at this archaeological site and adjacent locations (Fig. 1).

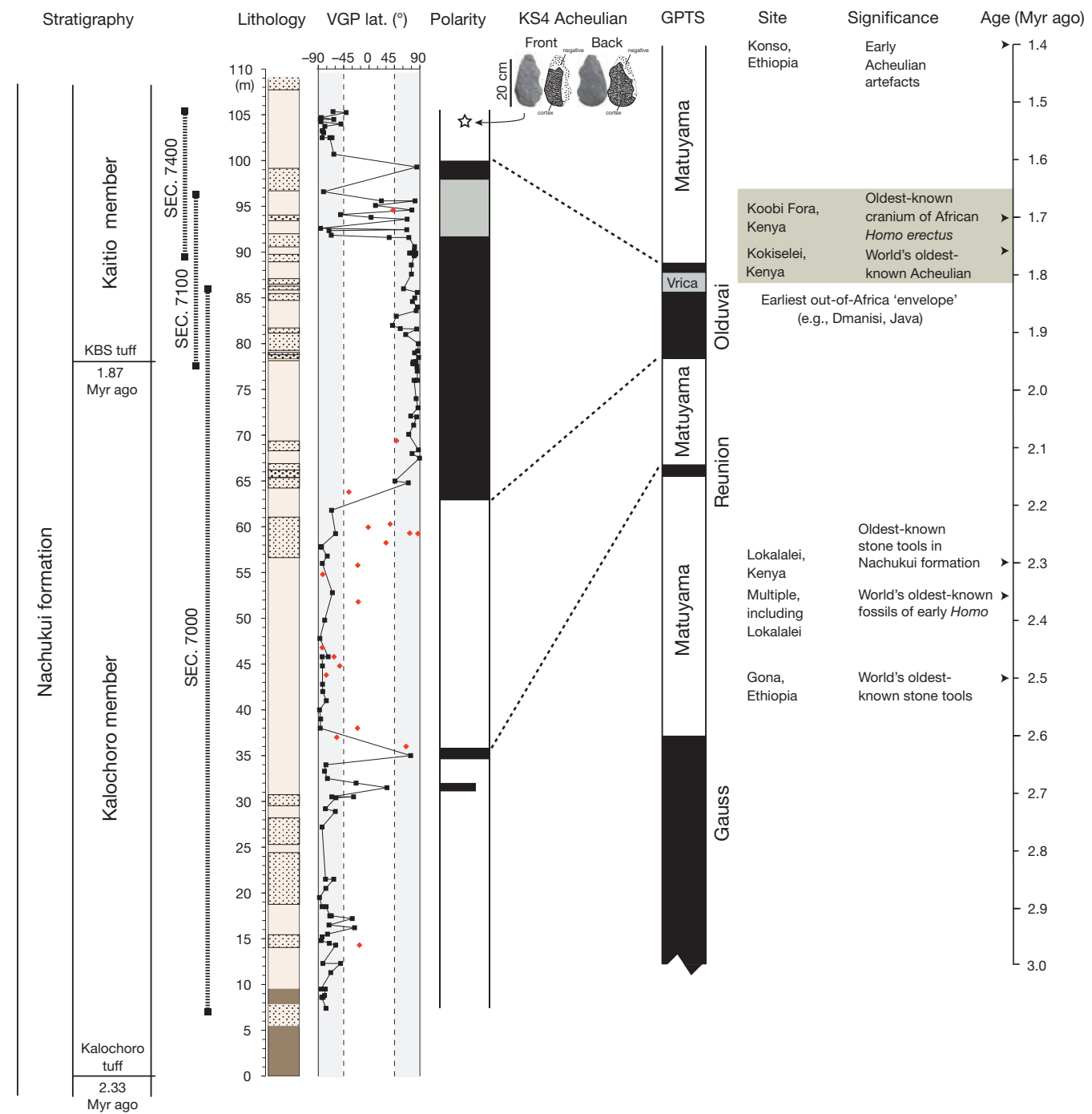

Figure $2 \mid$ Summary diagram. Left: members and tephrochronology ${ }^{11,15,16}$, lithostratigraphy (brown, tuff/bentonite; buff, mudstone; small circles, sand; large circles, gravel) and virtual geomagnetic pole (VGP) latitudes (primary group (black symbols, $n=129$ ) consists of reliable characteristic remanent magnetization directions; secondary group (red symbols, $n=19$ ), unreliable) of the examined interval of the Nachukui formation. Right: the Early Stone Age in eastern Africa (refs 2, 3, 8, 12, 19, 25, 26 and this study) referenced to the geological ages of the oldest known out-of-Africa sites with hominin fossils ${ }^{9,10}$ and the reversal chronology and age scale of the geomagnetic polarity timescale $(\mathrm{GPTS})^{17,23}$ 
Our palaeomagnetic results allow us to recognize three main polarity intervals for the overall composite magnetostratigraphy from the examined interval for the Nachukui formation (Fig. 2). A lowest interval of almost entirely reverse polarity extends from $7 \mathrm{~m}$ to $63.5 \mathrm{~m}$ above the base of the Kalochoro member/tuff. The following interval of mostly normal polarity begins at $63.5 \mathrm{~m}$ above the base of the Kalochoro member/tuff and extends to approximately $100 \mathrm{~m}$ above the base. Overlying this long mostly normal magnetozone is a 5-m-thick interval of exclusively reverse polarity. ${ }^{40} \mathrm{Ar} /{ }^{39} \mathrm{Ar}$ dating of the Kalochoro tuff ( $\sim 2.33 \mathrm{Myr}$ ago $)$ and the KBS tuff $(\sim 1.87 \mathrm{Myr}$ ago $)$ permits us to correlate accurately our magnetostratigraphy to the geomagnetic polarity timescale (GPTS) (Fig. 2). The polarity reversal at $63.5 \mathrm{~m}$ that is bracketed by these tuffs most probably represents the transition from the reverse Matuyama chron to the ensuing normal Olduvai subchron. Accordingly, the polarity reversal at $\sim 100 \mathrm{~m}$ correlates with the subsequent transition from the normal Olduvai subchron to the ensuing part of the reverse Matuyama chron. This implies that the long, mostly normal magnetozone from $63.5 \mathrm{~m}$ to $100 \mathrm{~m}$ is the entire Olduvai subchron. Thus, the Olduvai in the Nachukui formation is evidently $36.5 \mathrm{~m}$ thick. Additional indications that we have located the extent of the Olduvai subchron in the Nachukui formation comes from the excellent agreement between the sedimentation rates for the overlapping intervals of the Kalochoro to KBS tuffs $\left(\sim 17 \mathrm{~cm} \mathrm{kyr}^{-1}\right)$ and the identified base to top of the Olduvai subchron $\left(\sim 22 \mathrm{~cm} \mathrm{kyr}^{-1}\right)$. If our outcrop sampling strategy was compromised by poor correlations, not enough vertical stratigraphic coverage, or unconformities, for example, then these two sets of independently derived sedimentation rates would be much more divergent, which is not the case-in fact, the experimental error associated with the radio-isotopic dates of the tuffs makes the two sets of sedimentation rates empirically indistinguishable.

At 28.5 and $32 \mathrm{~m}$ beneath the base of the Olduvai, our findings indicate the presence of two stratigraphic levels-each represented by one specimen-with positive inclinations and northerly virtual geomagnetic pole (VGP) latitudes that may correlate with the Reunion subchron. The positive inclination associated with the lower of the two levels might be the result of incomplete removal of a hightemperature magnetic component of specimen P022a carrier by hematite; however, the normal polarity associated with the upper level derives from well-resolved data of specimen 715-3a, which is more likely to represent the Reunion subchron (2.128-2.148 Myr ago ${ }^{17}$ ). Other work on the Turkana basin sequences and correlative deposits in southwest Ethiopia has documented the Reunion subchron occurring as two normal polarity intervals ${ }^{18}$.

Our results reveal a complex, fine-scale pattern characterized by several short polarity excursions near the Olduvai to Matuyama boundary that is not unique to this particularly locality. It has been reported in this interval at other Turkana basin sequences ${ }^{19}$, in oceanic cores $^{20,21}$ and at the former Plio-Pleistocene boundary and point stratotype section at Vrica from the eastern Mediterranean sapropel sequences ${ }^{17,22,23}$. The origins of the fine-scale structure characteristic of the top of the Olduvai subchron found at Turkana (ref. 19 and this study) and elsewhere $e^{17,20-23}$ remain unclear, but might relate to the drop in the intensity of the geomagnetic field associated with the polarity reversal. The weak magnetic remanence of the sediment deposited in this low-intensity field may be more prone to resetting or overprinting in younger and comparatively stronger fields. Recent work suggests that such polarity excursions observed at Vrica could also reflect oxidation effects on the iron-bearing grains in the sapropel sequences ${ }^{24}$. Considering that post-Nachukui formation alluvial sediments mantle places of the landscape near KS4, some younger depositional or perhaps soil processes may have caused magneto-chemical alterations that might contribute to some of the complexity. Nevertheless, the similar palaeomagnetic reversal character for the end Olduvai at sites in different global geographic settings offers an exceptional correlation tool and provides additional support for our magnetostratigraphic interpretations. The stratigraphic position of
KS4 is $4.5 \mathrm{~m}$ above the Olduvai to Matuyama boundary. An age model based on a cubic spline fit to six chronostratigraphic tie-points (Kalochoro tuff, Reunion subchron, base of the Olduvai subchron, KBS tuff, top of the Olduvai subchron, and Lower Koobi Fora tuff) provides an estimate of $1.76 \mathrm{Myr}$ ago for the KS4 Acheulian assemblage (Fig. 3, see also Methods). This is more than $350 \mathrm{kyr}$ older than the early Acheulian artefacts from Konso, Ethiopia ${ }^{3}$.

An origin for the Acheulian back to $1.76 \mathrm{Myr}$ ago is close in age to partial cranium KNM-ER $3733^{19}$, which is ostensibly the most definitive evidence for the antiquity of African Homo erectus sensu lato, considering it is arguably a more anatomically diagnostic specimen, and thus better understood taxonomically as compared to possible conspecific fossils older than $1.7 \mathrm{Myr}^{25}$. Several hypotheses link the development of the Acheulian with the initial evolution of $H$. erectus. This is mainly because of a similar geographic origin for the two ${ }^{8}$, and the large-brained species persisted when many, if not all other, Homo taxa went extinct ${ }^{26}$ during the evolution of the characteristically made Acheulian post-1.5-Myr ago. An earlier Acheulian origin, coeval with sympatric Homo species ${ }^{26}$, strengthens the possibility that more than one tool-making hominin existed at 2.0-1.5 Myr ago.

Homo erectus is traditionally thought to be the first hominin to disperse from Africa, yet the oldest known out-of-Africa fossil hominin sites lack stone tools or preserve only Oldowan-style artefacts ${ }^{9,10}$. If indeed the first out-of-Africa hominin possessed Acheulian technology, then it is expected that evidence of this techno-culture should also be found dispersed throughout the Old World. However, archaeological sites older than $\sim 1$ Myr preserving the Acheulian are not abundantly documented from the Middle East, Europe or Asia, and are younger than the oldest known out-of-Africa hominin fossil localities dated at 1.7 Myr ago ${ }^{4-6,9,10}$. Our data indicate that the earliest development of the Acheulian occurred in Africa at $1.76 \mathrm{Myr}$ ago and was contemporaneous with or perhaps pre-dated the earliest hominin dispersals into Eurasia. Yet, the difference between the ages for the oldest known Acheulian artefacts in the world from Africa and the oldest known Acheulian artefacts from Eurasia raises the likelihood that the first Eurasian hominins derived from an African population lacking Acheulian culture. Potentially, two hominin groups coexisted in Africa at $1.76 \mathrm{Myr}$ ago. One of these groups could have developed the

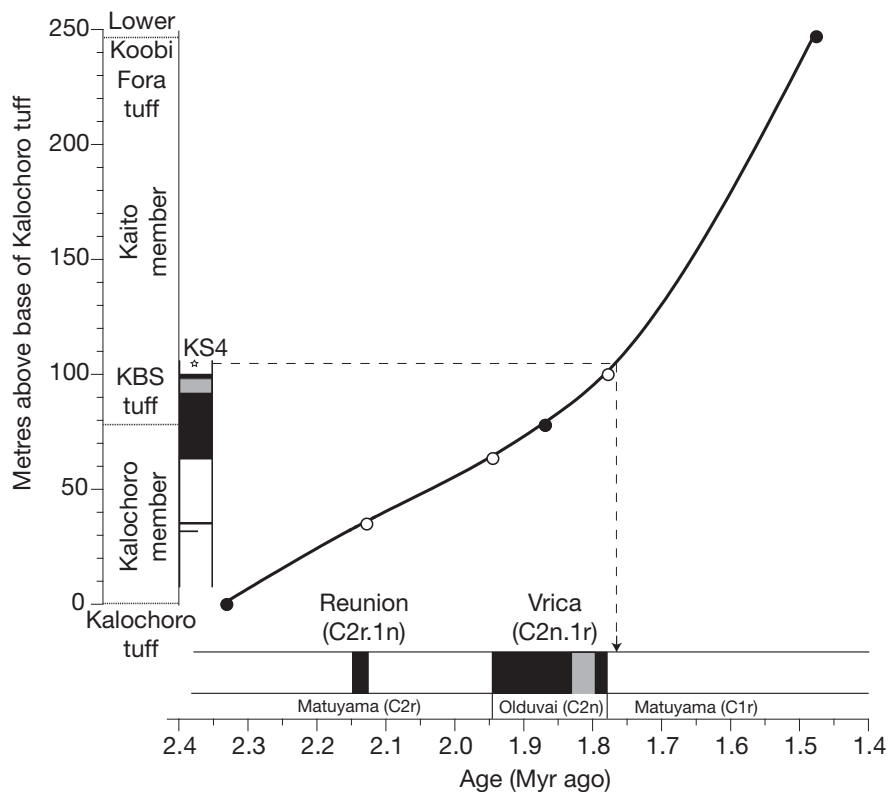

Figure $3 \mid$ Age model. Cubic spline curve fitted to stratigraphic levels above the Kalochoro tuff versus age of magnetostratigraphic subchrons ${ }^{17,23}$ (open circles) and dated tuffs ${ }^{15,16}$ (filled circles); dashed line shows how the stratigraphic level of KS4 was used to derive its age (1.76 Myr ago) from the spline curve. 
Acheulian technology but remained in Africa. The other could have lacked the cognitive ability and/or technological knowledge to manufacture the Acheulian technology and did not carry it into Eurasia. This division may indicate different behavioural aptitudes for separate African species (for example, $H$. erectus sensu lato versus Homo habilis sensu lato) or a within-species cultural disparity. In any event, it seems that a second hominin dispersal with Acheulian technology or a diffusion of this technology took place later, leading to the widespread occurrence of this Early Stone Age tradition in the circumMediterranean area and elsewhere after $\sim 1 \mathrm{Myr}$ ago $^{4,5}$.

\section{METHODS SUMMARY}

Orientations by magnetic compass and clinometer of planar faces were marked before removing hand-cut blocks from outcrops. Samples were taken at one-metre intervals or as the occurrence of fine-grained strata permitted. At least one independent block sample was taken from each interval resulting in 148 independent samples, from which one or more specimens were cut for processing. Magnetic remanence measurements were made with a 2G Model 760 DC-SQUID rock magnetometer in the shielded room of the Paleomagnetics Laboratory at Lamont-Doherty Earth Observatory. Natural remanent magnetizations of all sample specimens were subjected to progressive thermal demagnetization using an initial step of $100^{\circ} \mathrm{C}$, seven steps at $50^{\circ} \mathrm{C}$ increments to $450^{\circ} \mathrm{C}$, and five steps at $25^{\circ} \mathrm{C}$ increments to $575^{\circ} \mathrm{C}$. Magnetic susceptibility values were determined with a Bartington MS2B instrument initially and after each heating step to monitor for magneto-chemical alteration. Virtual geomagnetic pole (VGP) latitudes were calculated from the characteristic remanent magnetization (ChRM) directions determined from principal component analysis ${ }^{27}$ and Zijderveld demagnetization diagrams $^{28}$ (Supplementary Table 1). Reliable ChRM directions are characterized by maximum angular deviation (MAD) values of less than $15^{\circ}$ of a component that linearly converges towards the origin over five high-temperature steps. VGP latitude for each specimen was plotted in stratigraphic position to determine magnetostratigraphy.

The numerical age of KS4 was estimated through a model of the rate of sediment accumulation for the deposits encasing the site using a cubic spline function through data for the Kalochoro tuff $\left(0 \mathrm{~m}, 2.331 \mathrm{Myr}^{\mathrm{ago}}{ }^{16}\right)$, Reunion subchron ( $35 \mathrm{~m}$, midpoint $2.138 \mathrm{Myr}$ ago $\left.^{17,23}\right)$, base of Olduvai subchron $(63.5 \mathrm{~m}, 1.945 \mathrm{Myr}$ ago $\left.{ }^{17,23}\right)$, KBS tuff $\left(78 \mathrm{~m}, 1.869 \mathrm{Myr}\right.$ ago $\left.^{15}\right)$, top of Olduvai subchron $(100 \mathrm{~m}$, $\left.1.778 \mathrm{Myr}_{\mathrm{ago}}{ }^{17,23}\right)$, and Lower Koobi Fora tuff $\left(247 \mathrm{~m}, 1.476 \mathrm{Myr}_{\mathrm{ago}}{ }^{15}\right)$. This method places the KS4 Acheulian assemblage $(104.5 \mathrm{~m})$ at $1.76 \mathrm{Myr}$ ago.

\section{Received 8 June; accepted 13 July 2011.}

1. Leakey, M. Olduvai Gorge: Excavations in Beds I \& // 1960-1963 (Cambridge Univ. Press, 1971).

2. Isaac, G., LI. \& Curtis, G. H. Age of early Acheulean industries from the Peninj Group, Tanzania. Nature 249, 624-627 (1974).

3. Asfaw, B. et al. The earliest Acheulean from Konso-Gardula. Nature 360, 732-735 (1992).

4. Goren-Inbar, N. etal. Pleistocene milestones on the out-of-Africa corridor at Gesher Benot Ya'aqov, Israel. Science 289, 944-947 (2000).

5. Scott, G. R. \& Gibert, L. The oldest handaxes in Europe. Nature 461, 82-85 (2009).

6. Pappu, S. et al. Early Pleistocene presence of Acheulian hominins in south India. Science 331, 1596-1599 (2011).

7. Gowlett, J. A. J. in Stone Age Prehistory (eds Bailey, G. N. and Callow, O.) 243-260 (Cambridge Univ. Press, 1986).

8. Klein, R. The Human Career: Human Biological and Cultural Origins $3^{\text {rd }}$ edn (University Chicago Press, 2009).

9. Swisher, C. C. III, Curtis, G. H., Jacob, T., Getty, A. G. \& Suprijo, A. Age of the earliest known hominids in Java, Indonesia. Science 263, 1118-1121 (1994).

10. Gabunia, L. et al. Earliest Pleistocene hominid cranial remains from Dmanisi, Republic of Georgia: taxonomy, geological setting, and age. Science $\mathbf{2 8 8}$ 1019-1025 (2000).

11. Harris, J. M., Brown, F. H. \& Leakey, M. G. Geology and paleontology of PlioPleistocene localities west of Lake Turkana, Kenya. Contrib. Sci. 399, 1-128(1988).
12. Roche, H. et al. Les sites archéologiques plio-pléistocènes de la formation de Nachukui, Ouest-Turkana, Kenya: bilan synthétique 1997-2001. C. R. Palevol 2 , 663-673 (2003).

13. Harmand, S. Raw material and economic behaviours at Oldowan and Acheulean sites in the West Turkana region, Kenya. In Lithic Materials and Paleolithic Societies (eds Adams, B. \& Blades, B.). 3-14 (Wiley-Blackwell, 2009).

14. Feibel, C. S. Harris, J. M. \& Brown, F. H. in Koobi Fora Research ProjectVol. 3 The Fossil Ungulates: Geology, Fossil Artiodactyls, and Palaeoenvironments (ed. Harris, J. M.) 321-370 (Clarendon, 1991).

15. McDougall, I. \& Brown, F. H. Precise ${ }^{40} \mathrm{Ar} /{ }^{39} \mathrm{Ar}$ geochronology for the upper Koobi Fora Formation, Turkana Basin, northern Kenya. J. Geol. Soc. Lond. 163, 205-220 (2006).

16. McDougall, I. \& Brown, F. H. Geochronology of the pre-KBS Tuff sequence, Omo Group, Turkana Basin. J. Geol. Soc. Lond. 165, 549-562 (2008).

17. Lourens, L., Hilgen, F., Shackleton, N. J., Laskar, J. \& Wilson, D. in A Geologic Time Scale (eds Gradstein, F., Ogg, J. \& Smith, A.) 409-440 (Cambridge Univ. Press, 2004).

18. Kidane, T., Otofuji, Y.-I., Brown, F. H., Takemoto, K. \& Eshete, G. Two normal paleomagnetic polarity intervals in the lower Matuyama Chron recorded in the Shungura Formation (Omo Valley, Southwest Ethiopia). Earth Planet. Sci. Lett. 262 240-256 (2007).

19. Lepre, C. J. \& Kent, D. V. New magnetostratigraphy for the Olduvai Subchron in the Koobi Fora Formation, northwest Kenya, with implications for early Homo. Earth Planet. Sci. Lett. 290, 362-374 (2010).

20. Ninkovich, D., Opdyke, N. D., Heezen, B. C. \& Foster, J. H. Paleomagnetic stratigraphy, rates of deposition and tephrachronology in North Pacific deep-sea sediments. Earth Planet. Sci. Lett. 1, 476-492 (1966).

21. Clement, B. M. \& Kent, D. V. Geomagnetic polarity transition records from five hydraulic piston core sites in the North Atlantic. Initial Rep. Deep Sea Drill. Proj. 94, 831-852 (1987).

22. Tauxe, L., Opdyke, N. D.,Pasini, G. \& Elmi, C. Age of the Plio-Pleistocene boundary in the Vrica section, southern Italy. Nature 304, 125-129 (1983).

23. Zijderveld, J. D. A., Hilgen, F. J., Langereis, C. G., Verhallen, P. J. J. M. \& Zachariasse W. J. Integrated magnetostratigraphy and biostratigraphy of the upper Pliocenelower Pleistocene from the Monte Singa and Crotone areas in Calabria, Italy. Earth Planet. Sci. Lett. 107, 697-714 (1991).

24. Roberts, A. P., Florindo, F., Larrasoaña, J. C., O'Regan, M. A. \& Zhao, X. Complex polarity pattern at the former Plio-Pleistocene global stratotype section at Vrica (Italy): Remagnetization by magnetic iron sulphides. Earth Planet. Sci. Lett. 292, 98-111 (2010)

25. Wood, B. A. Koobi Fora Research Project Vol. 4 Hominid Cranial Remains from Koobi Fora (Clarendon, Oxford, 1991).

26. Spoor, F. et al. Implications of new early Homo fossils from lleret, east of Lake Turkana, Kenya. Nature 448, 688-691 (2007).

27. Kirschvink, J. L. The least-squares line and plane and the analysis of palaeomagnetic data. Geophys. J. R. Astron. Soc. 62, 699-718 (1980).

28. Zijderveld, J. D. A. A. C. in Methods in Paleomagnetism (eds Collinson, D. W., Creer, K M. \& Runcorn, S. K.) 254-286 (Elsevier, 1967).

Supplementary Information is linked to the online version of the paper at www.nature.com/nature.

Acknowledgements We thank the office of the President of Kenya and the National Museums of Kenya for permission to conduct this research, TOTAL Kenya for logistical support, and the WTAP team. Funding was provided by the French Ministry of Foreign Affairs and the National Science Foundation (BCS 02-18511 to C.S.F.) Lamont-Doherty Earth Observatory is acknowledged for ongoing support to the Paleomagnetics Laboratory.

Author Contributions C.J.L. recorded field sedimentological and stratigraphic data, collected and analysed geological samples, interpreted palaeomagnetic data, and wrote the overall paper. H.R. oversaw archaeological excavations, analysed and interpreted archaeological material, and wrote sections of the paper. D.V.K. analysed geological samples, interpreted palaeomagnetic data, and edited the paper. S.H. conducted archaeological excavations, analysed and interpreted the archaeological material, and wrote sections of the paper. R.L.Q. recorded field sedimentological and stratigraphic data, collected geological samples, and edited the paper. J.-P.B. analysed and interpreted fossil material. P.-J.T. analysed and interpreted archaeological material. A.L. conducted geological mapping. C.S.F. recorded field sedimentological and stratigraphic data and conducted geological mapping.

Author Information Reprints and permissions information is available at www.nature.com/reprints. The authors declare no competing financial interests. Readers are welcome to comment on the online version of this article at www.nature.com/nature. Correspondence and requests for materials should be addressed to C.J.L. (lepre@ldeo.columbia.edu). 